\title{
Influence of Rate, Timing, and Method of Nitrogen Fertilizer Application on Uptake and Use of Fertilizer Nitrogen, Growth, and Yield of June-bearing Strawberry
}

\author{
Bernadine Strik, ${ }^{1}$ Timothy Righetti, ${ }^{2}$ and Gil Buller ${ }^{3}$ \\ Department of Horticulture, Oregon State University, 4017 ALS, Corvallis, OR 97331-7304
}

AdDITIONAL INDEX WORDS. Fragaria $\times$ ananassa, ${ }^{15} \mathrm{~N}$, nitrate, partitioning, mobilization, fertilizer use efficiency, foliar feeding, matted row, perennial production, spring fertilization, nutrition, yield, fruit quality

\begin{abstract}
Fertilizer nitrogen (FN) recovery, and changes in nitrogen $(\mathrm{N})$ and dry weight partitioning were studied over three fruiting seasons in June-bearing strawberry (Fragaria xananassa Duch. 'Totem') grown in a matted row system. Fertilizer nitrogen treatments were initiated in 1999, the year after planting. The standard ammonium nitrate $\mathrm{N}$ application at renovation $\left(55 \mathrm{~kg} \cdot \mathrm{ha}^{-1}\right.$ of $\left.\mathrm{N}\right)$ was compared to treatments where additional $\mathrm{N}$ was applied. Supplemental treatments included both ground-applied granular ammonium nitrate $\left(28 \mathrm{~kg} \cdot \mathrm{ha}^{-1} \mathrm{of} N\right)$ applied early in the season and foliar urea [5\% (weight/volume); $16 \mathrm{~kg} \cdot \mathrm{ha}^{-1}$ of $\mathrm{N}$ ] applied early in the season and after renovation. When labeled $\mathrm{N}$ was applied (eight of nine treatments) it was applied only once. The impact of no FN from the second through the third fruiting season was also evaluated. Fertilizer nitrogen treatment had no impact on total plant dry weight, total plant $N$, yield or fruit quality from the first through the third fruiting seasons. Net dry matter accumulation in the first fruiting season was $2 \mathrm{t} \cdot \mathrm{ha}^{-1}$ not including the $4 \mathrm{t} \cdot \mathrm{ha}^{-1}$ of dry matter removed when leaves were mowed during the renovation process. Seasonal plant dry weight and $\mathrm{N}$ accumulation decreased as the planting aged. Net nitrogen accumulation was estimated at $40 \mathrm{~kg} \cdot \mathrm{ha}^{-1}$ from spring growth to dormancy in the first fruiting season (including $30 \mathrm{~kg} \cdot \mathrm{ha}^{-1}$ in harvested fruit, but not including the $52 \mathrm{~kg} \cdot \mathrm{ha}^{-1}$ of $\mathrm{N}$ lost at renovation). Recovery of fertilizer $\mathrm{N}$ ranged from $42 \%$ to $63 \%$ for the broadcast granular applications and $15 \%$ to $52 \%$ for the foliar FN applications, depending on rate and timing. Fertilizer $\mathrm{N}$ from spring applications (granular or foliar) was predominantly partitioned to leaves and reproductive tissues. A large portion of the spring applied FN was lost when plants were mowed at renovation. Maximum fertilizer use efficiency was $42 \%$ for a granular $55 \mathrm{~kg} \cdot \mathrm{ha}^{-1}$ application at renovation, but declined to $42 \%$ just before plant growth the following spring, likely a result of $\mathrm{FN}$ loss in leaves that senesced. In June, $\approx 30 \%$ of the $\mathrm{N}$ in strawberry plants was derived from FN that was applied at renovation the previous season, depending on year. This stored $\mathrm{FN}$ was reallocated to reproductive tissues $(22 \%$ to $35 \%)$ and leaves (43\% to $53 \%$ ), depending on year. Applying fertilizer after renovation increased the amount of remobilized $\mathrm{N}$ to new growth the following spring. The following June, $15 \%$ of plant nitrogen was derived from fertilizer applied at renovation 2 years prior.
\end{abstract}

Nitrogen fertilizer studies in strawberry (Fragaria $\times$ ananassa Duch.) have shown varying results depending on many factors including type of strawberry, production system, application method, and soil type. In annual production systems, fertilizer nitrogen (FN) at planting has increased yield (Albregts and Howard, 1981, 1986) or has had no effect in some years (Albregts and Sutton, 1971; Rodgers et al., 1985). Miner and co-workers (1997) found greatest yield of 'Chandler' in annual production with a split application of FN in spring and fall. Spring FN has been shown to reduce fruit quality (Voth et al., 1967).

In perennial matted row production systems increased rates of FN in the planting year led to increased FN recovery, but there was no relationship with yield in the following fruiting season (Archbold and MacKown, 1988, 1995, 1997). Breen (1979) also found no effect of FN in the planting year on yield the following season. In contrast, some have shown a reduced yield in the first fruiting season when no FN was applied in the planting year (Cutcliffe and Blatt, 1984; Latet et al., 2002).

Responses to FN applied in the fruiting season have been variable with higher FN rates increasing yield in some studies (Albregts and Howard, 1973; Cutcliffe and Blatt, 1984; Latet et al., 2002), positive yield responses to FN in only some years of a multiyear study

Received for publication 9 June 2003. Accepted for publication 24 Oct. 2003. The authors thank the Oregon Strawberry Commission for supporting this research and Helen Cahn and Jason Lett for technical assistance.

1Professor, berry crops research leader, North Willamette Research and Extension Center; e-mailstrikb@science.oregonstate.edu.

${ }^{2}$ Professor.

${ }^{3}$ Research assistant, North Willamette Research and Extension Center.
(Albregts and Sutton, 1971; Karp et al., 2002; Kirsch, 1959; Ullrich and Martin, 1987), to no effect of FN on yield compared to an unfertilized treatment (Blatt, 1981; Breen, 1979; Rodgers et al., 1985). In some studies, high rates of FN have decreased yield or quality (Albregts and Howard, 1973; Darrow and Waldo, 1932). Application of FN in the spring of a fruiting season, rather than the more standard application at renovation after harvest (Hart et al., 2000; Pritts and Handley, 1998), has increased the quantity of nonmarketable fruit (Kirsch, 1959), perhaps a result of increased susceptibility of blossoms to spring frost damage (Ullrich and Martin, 1987).

Uptake, partitioning of FN, and how stored $\mathrm{N}$ is used in the fruiting season of field-grown strawberry in perennial production systems have not been well documented. Archbold and MacKown (1988) found that FN applied in the planting year was equally partitioned to vegetative and fruiting tissues during fruiting the following year. The total $\mathrm{N}$ content of leaves was high relative to crown and root N content in June (Archbold and MacKown, 1995). Archbold and MacKown (1988) speculated that $\mathrm{N}$ remaining in the vegetative tissues following fruit harvest could be recycled during subsequent growing seasons. However, in perennial production systems, strawberry plants are mowed during the renovation process after harvest, removing all leaves present and likely a significant portion of the total $\mathrm{N}$ present in the plant. The $\mathrm{N}$ present in mowed leaves could be recycled back into the plant over time. However, it is not presently known what impact renovation has on the total $\mathrm{N}$ budget and the fate of previous FN applied.

Foliar application of fertilizers may have benefits, particularly when a nutrient can be applied during periods of rapid growth, 
when the availability of soil nutrients is inadequate or restricted, or to supply a relatively immobile nutrient at a critical time of year (Boynton, 1954; Swietlik and Faust, 1984). Fruit crop responses to foliar FN applications have been inconsistent. In strawberries, foliar fertilizer applications of nitrogen, phosphorus, and potassium have had no effect (Karp et al., 2002; Rosen et al., 1988) or only had an effect when the soil nutrient levels were considered inadequate (Albregts and Howard, 1986). The actual rate of nitrogen applied in the foliar application studies in strawberry has been low (1.2 to 6.0 $\mathrm{kg} \cdot \mathrm{ha}^{-1}$ ), because higher rates were thought to cause phytotoxicity (Albregts and Howard, 1986). The uptake of foliar applications of urea has been studied in many crops (i.e. Bondada et al., 2001; Khemira et al., 1999; Orbovic et al., 2001; Reickenberg and Pritts, 1996). Absorption of urea has ranged from $26 \%$ in red raspberry (Rubus sp. L.) (Reickenberg and Pritts, 1996) to 60\% in grapefruit, Citrus paradisi Macf. (Orbovic et al., 2001) after 24 to 32h. Rates as high as $5 \% \mathrm{~N}$ (at $23.3 \mathrm{~g} \cdot \mathrm{L}^{-1}$ or $35 \mathrm{~kg} \cdot \mathrm{ha}^{-1}$ of $\mathrm{N}$ ) urea in solution have been applied without phytotoxicity (Bondada et al., 2001). Although the impact of spring applied foliar fertilizers containing $\mathrm{N}$ has been studied in strawberry (Albregts and Howard, 1986; Karp et al., 2002; Rosen et al., 1988), the fate of foliar FN and the effect of late-season applications is not well understood. In apple (Malus $\times$ domestica Borkh.), foliar urea sprays applied after fruit harvest or in the fall contributed more to bud nitrogen content than spring applied foliar urea (Khemira et al., 1999).

Additional studies on whether altering nitrogen management increases yield in various strawberry production systems are unlikely to clarify a complex issue. The literature clearly suggests that results vary and a nitrogen fertilizer related yield response is often not observed, especially in perennial systems. By understanding the fate of nitrogen that is applied and the biological significance of any partitioning and nitrogen use efficiency differences amongst treatments we may better interpret and evaluate the variable results commonly reported.

The objectives of this study were to 1 ) use ${ }^{15} \mathrm{~N}$-depleted fertilizer to study the accumulation, partitioning and remobilization of FN, over a 3-year period in 'Totem' June-bearing strawberry grown in a perennial, matted row production system; and 2) determine the impact of rate, timing, and method of fertilizer nitrogen application on $\mathrm{N}$ uptake, partitioning, strawberry plant growth, yield, and fruit quality over three fruiting seasons.

\section{Materials and Methods}

STUdY PLANTS. The experiment was conducted at the North Willamette Research and Extension Center, Aurora, Ore. Strawberry (Fragaria $\times$ ananassa 'Totem') plants were established 8 June 1998 using dormant cold-stored crowns. Plants were spaced $0.4 \mathrm{~m}$ within rows spaced $1 \mathrm{~m}$ apart $(25,822$ plants/ha) on raised beds $(\approx 0.3 \mathrm{~m}$ high and $0.4 \mathrm{~m}$ wide). The planting was on a Quatama series soil (fine-loamy, mixed mesic Aqualtic Haploxeralfs). Fertility management was designed to match our best perception of current local practices. In the planting year, $56 \mathrm{~N}-50 \mathrm{P}-93 \mathrm{~K} \mathrm{~kg} \cdot \mathrm{ha}^{-1}$ was applied as a triple split (33\%:33\%:33\%) in June, July, and August. During the course of this study, only the $\mathrm{N}$ fertilization rates, methods and timings were changed. All treatments received $50 \mathrm{P}-93 \mathrm{~K} \mathrm{~kg} \cdot \mathrm{ha}^{-1}$ at renovation in 1999 and 2000. The research planting was sprayed with pesticides, as necessary, to manage any insect, disease, or weeds present. If rainfall was inadequate, irrigation was provided by overhead irrigation at a rate of $\approx 2.5 \mathrm{~cm} /$ week during the growing season. In the first and second fruiting seasons, the planting was renovated on 22 July 1999 and 9 July 2000, respectively, by mowing off the foliage above the crown (this was left in the field on and beside the rows), applying fertilizer, and irrigating. The matted rows were maintained to $0.4 \mathrm{~m}$ wide. No thinning of crowns within the matted row was done.

TreatMenTs. Fertilizer nitrogen (FN) treatments were initiated in 1999, the first fruiting season or the year after planting. Treatments one through six were treated with ${ }^{15} \mathrm{~N}$-depleted $\mathrm{FN}$ at the rates, methods and dates presented in Table 1. Labeled fertilizer $\left({ }^{15} \mathrm{~N}\right.$ depleted) was only applied in 2000 in treatments 7 and 9 (Table 1). Treatment 8 received no FN in 2000 and 2001 (Table 1). The spring granular FN (treatment 1) and all the foliar FN treatments (3-6 and 9) were in addition to the industry standard (Hart et al., 2000) 55 $\mathrm{kg} \cdot \mathrm{ha}^{-1}$ of $\mathrm{N}$, applied just after renovation (Table 1$)$. Treatments 2 and 7 were considered the industry standard (Table 1).

The fertilizer used for all applications was granular ammonium nitrate $\left(\mathrm{NH}_{4} \mathrm{NO}_{3}\right)$. Plots that received labeled $\mathrm{FN}$ were treated with ammonium nitrate depleted in ${ }^{15} \mathrm{~N}\left(0.05\right.$ atom $\%{ }^{15} \mathrm{~N}$, ICON Services Inc., Summit, N.J.) at the rates provided in Table 1. Granular FN was applied in a broadcast band the width of the matted row $(0.4$ $\mathrm{m})$ and the length of each treated plot $(10.7 \mathrm{~m})$. The planting was overhead irrigated with $\approx 2.5 \mathrm{~cm}$ of water right after application

Table 1. Nitrogen fertilization rates for nine treatments studied from 1998-2000 in 'Totem' strawberry.

\begin{tabular}{|c|c|c|c|c|c|c|c|c|c|c|c|}
\hline \multirow{3}{*}{ Treatment } & \multicolumn{11}{|c|}{ Nitrogen fertilization historyz } \\
\hline & \multirow{2}{*}{$\begin{array}{c}1998 \\
55 \mathrm{~kg} \cdot \mathrm{ha}^{-1} \\
\text { in planting } \\
\text { year }\end{array}$} & \multicolumn{6}{|c|}{1999} & \multicolumn{4}{|c|}{2000} \\
\hline & & $28 \mathrm{~kg} \cdot \mathrm{ha}^{-1}$ & Foliary & Foliar & $\begin{array}{l}55 \mathrm{~kg} \cdot \mathrm{ha}^{-1} \\
\text { Renovation } \\
28 \mathrm{Julv}\end{array}$ & Foliar & Foliar & $28 \mathrm{~kg} \cdot \mathrm{ha}^{-1}$ & Foliar & $\begin{array}{l}55 \mathrm{~kg} \cdot \mathrm{ha}^{-1} \\
\text { Renovation }\end{array}$ & Foliar \\
\hline 1 & $x$ & $\mathrm{x}^{*}$ & & & - & & & $\mathrm{x}$ & & $\mathrm{x}$ & \\
\hline 2 & $\mathrm{X}$ & & & & $\mathrm{X}^{*}$ & & & & & $\mathrm{X}$ & \\
\hline 3 & $\mathrm{X}$ & & $\mathrm{X}^{*}$ & & $\mathrm{X}$ & & & & $\mathrm{x}$ & $\mathrm{x}$ & \\
\hline 4 & $\mathrm{X}$ & & & $\mathrm{X}^{*}$ & $\mathrm{x}$ & & & & & & \\
\hline 5 & $\mathrm{x}$ & & & & $\mathrm{x}$ & $\mathrm{x}^{*}$ & & & & & \\
\hline 6 & $\mathrm{X}$ & & & & $\mathrm{X}$ & & $\mathrm{x}^{*}$ & & & & \\
\hline 7 & $\mathrm{x}$ & & & & $\mathrm{x}$ & & & & & $\mathrm{X}^{*}$ & \\
\hline 8 & $\mathrm{x}$ & & & & $\mathrm{x}$ & & & & & & \\
\hline 9 & $\mathrm{x}$ & & & & $\mathrm{x}$ & & & & & $\mathrm{X}$ & $\mathrm{x}^{*}$ \\
\hline
\end{tabular}

${ }^{2}$ Nitrogen fertilizer was applied either as granular (just rate provided) or foliar only on the dates indicated with $\mathrm{x}$. All treatments received the same rate of phosphorus and potassium fertilization. $\mathrm{x}^{*}=$ indicates ${ }^{15} \mathrm{~N}$-depleted fertilizer (ammonium nitrate) was applied on that date.

yFoliar fertilizer was applied as a $5 \%$ urea solution in $700 \mathrm{~L} \cdot \mathrm{ha}^{-1}$ of water $\left(23 \mathrm{~g} \cdot \mathrm{L}^{-1}\right.$ of $\left.\mathrm{N}\right)$ to the treatment plot, a commercial rate/volume. $\mathrm{x}^{*}={ }^{15} \mathrm{~N}$ depleted urea was applied on that date. Foliar treatments were applied at full bloom (21 Apr.), at green fruit stage ( 2 June), early postrenovation (11 Aug.), or late postrenovation (8 Sept.). 
of FN with the exception of treatment 2 when the plot was handwatered at an equivalent rate to prevent the foliar application in treatment three (Table 1) from receiving overhead irrigation.

The foliar FN treatments received a 5\% solution (wt/v) of urea (0.05 atom \% ${ }^{15} \mathrm{~N}$, ICON Services Inc., Summit, N.J.) in water $\left(23 \mathrm{~g} \cdot \mathrm{L}^{-1}\right.$ of $\left.\mathrm{N}\right)$. Plots were treated in the early morning with the equivalent of $700 \mathrm{~L}$ of water per hectare, a commercial volume, thus applying $16 \mathrm{~kg} \cdot \mathrm{ha}^{-1}$ of N. Plants had a full canopy (closed) at each application date. On the days of foliar urea application weather conditions were 21 Apr. $1999\left(11^{\circ} \mathrm{C}\right.$ maximum, $2 \mathrm{~mm}$ precipitation); 2 June $1999\left(16^{\circ} \mathrm{C}\right.$, no precipitation, irrigated the following day); $8 \mathrm{Aug}$. $1999\left(18^{\circ} \mathrm{C}\right.$, no precipitation, irrigated the following day); 8 Sept. $1999\left(32^{\circ} \mathrm{C}\right.$, no precipitation, irrigated the following day); and $17 \mathrm{Oct} .2000\left(21^{\circ} \mathrm{C}\right.$, no precipitation until four days later, no irrigation).

Treatment plots consisted of a $10.7 \mathrm{~m}$ long section of matted row, flanked by $3 \mathrm{~m}$ sections of matted row on each end and by three matted rows on each side. Treatment plots were replicated three times and arranged in a randomized complete block design.

Data collected. To determine dry weight, total $\mathrm{N},{ }^{15} \mathrm{~N}$, and partitioning, whole plant samples were dug up throughout the experimental period, on each of the following dates in 1999: $22 \mathrm{Apr}$. (full canopy, just prior to bloom); 6 and 20 May; 3 June (before fruit harvest) and 17 June; 1 July (end of fruit harvest), 15 and 29 July (after renovation); 12 and 26 Aug.; 9 and 23 Sept.; 7 and 21 Oct.; and 4 and 18 Nov. (before dormancy); in 2000: 17 Feb. (just prior to new growth); 4 May; and 1 June; and in 2001: 28 Jan.; and 10 and 31 May. Whole plant sampling started one day after the FN treatment was applied and on each aforementioned date thereafter; for example, sampling for treatment 4 (Table 1) started on 3 June 1999 and continued through 31 May 2001. In addition, no samples were collected for treatments 7-9 (Table 1) in 1999. A whole plant sample was taken by digging up the mother plant (the original plant) and any attached daughters (runners) in a 0.4 $\mathrm{m}$ long section of matted row.

On each sampling date, the sampled plants were thoroughly washed with tap water and partitioned into roots, crowns, leaves (including petioles and stipules), daughters (runners still attached to mother plant including stolons), inflorescences (at bloom the entire structure; at fruiting without the fruit but with the calyx), green fruit, and red fruit, if present. Care was taken to ensure maximum recovery of roots. All dead plant material was discarded. Ripe fruit were freeze dried to a constant weight. The remaining separated tissues were bulked by type and dried at $40{ }^{\circ} \mathrm{C}$ to a constant weight and weighed to obtain dry weight for each tissue type. Each tissue type was separately mixed and homogenized in a large paper bag, and a random 50 to $100 \mathrm{~g}$ subsample of tissue selected and ground to pass a 0.6-mm (40-mesh) screen. Two-gram subsamples of each of the ground tissues were sent to Isotope Services (Los Alamos, N.M.) for analysis of total N concentration and ${ }^{15} \mathrm{~N}$ by mass spectrometry.

Ripe fruit were harvested weekly during the fruiting seasons of 1999-2001. Treatments 1 to 4 were compared for yield in 1999; treatments 1 to 6 in 2000; and treatments 1 to 3 and 7 and 9 in 2001 (Table 1). Yield was collected from a 3-m section of each treatment plot. In addition to yield on each harvest date, data were collected on average berry weight ( 25 berry subsample), weight of rotted fruit, percent soluble solids ( ${ }^{\circ}$ Brix; digital refractometer PR-100; ATAGO Co., Ltd., Tokyo, Japan), fruit firmness (Penetrometer, AMETEK Hunter Spring Division, Hatfield, Pa.), and percentage of drip loss. To determine drip loss, a 10-berry subsample was weighed, individually quick frozen, thawed in a sieve to allow leaching of juices, and fruit reweighed.
Atom percent values were converted to the proportion of the nitrogen derived from fertilizer (NDFF), using standard conversions (Hauck and Bremner, 1976):

$$
\left[\mathrm{NDFF}=\frac{\left({ }^{15} \mathrm{~N}_{\text {natural abundance }}\right)-\left(\text { atom } \%{ }^{15} \mathrm{~N}\right)_{\text {tissue }}}{\left({ }^{15} \mathrm{~N}_{\text {natural abundance }}\right)-\left(\text { atom } \%{ }^{15} \mathrm{~N}\right)_{\text {fertilizer }}}\right.
$$

The ${ }^{15} \mathrm{~N}$ natural abundance was assumed equal to 0.366 atom percent.

The presence of any residual ${ }^{15} \mathrm{~N}$ remaining in the soil was determined using barley (Hordeum vulgare L.) as an indicator plant. On 1 May 2000, 'Baronesse' spring barley was hand seeded directly in the areas where plants had been removed from treatment plots 2,6 , and 7 (a control plot receiving no ${ }^{15} \mathrm{~N}$; Table 1 ). The aboveground portion of the barley in a $0.4 \mathrm{~m}$ long section of row to match the location of fertilizer application was hand harvested on 1 June 2000, dried, ground, and analyzed for concentrations of $\mathrm{N}$ and ${ }^{15} \mathrm{~N}$ as described previously.

Sampling could not be randomized over time within treatment. Thus, the data for dry weight, total nitrogen and ${ }^{15} \mathrm{~N}$ content and concentration were analyzed by date and by plant part type for treatment effects using the general linear model procedure of SAS (SAS Institute Inc. 1990). Treatment effects on whole plant dry weight and nitrogen content and concentration were also analyzed. Based on plant dry weights, $\mathrm{N}$ content, and atom $\%{ }^{15} \mathrm{~N}$ values, $\mathrm{FN}$ recovery values or fertilizer use efficiency (FUE) were calculated. Trends over time are presented in graphs (mean $\pm \mathrm{SE}$ ) to more clearly show our findings. The means for yield and fruit quality were analyzed as described previously and were compared using a protected least significant difference (LSD) test.

\section{Results}

Plant DRy Weight. There was no significant effect of FN treatment on whole plant dry matter content on any date in 1999-2001. Thus, the data for treatments 1 through 6 (Table 1), for which a complete set of data were collected in 1999 and 2000, were pooled and are presented in Fig. 1.

Whole plant dry weight increased over 5-fold from April to early July 1999, reaching a plateau during fruiting (Fig. 1). On 22 Apr. 1999 estimated total dry matter was $1395 \mathrm{~kg} \cdot \mathrm{ha}^{-1}$. Total dry matter increased to a maximum of $7230 \mathrm{~kg} \cdot \mathrm{ha}^{-1}$ in the first fruiting season. Renovation or the physical act of mowing off leaves after harvest, led to a $70 \%$ decline in total plant dry weight. After renovation, dry weight accumulation was relatively slight before plants in all treatments entered dormancy (Fig. 1); total dry matter was estimated at $3330 \mathrm{~kg} \cdot \mathrm{ha}^{-1}$ on 18 Nov. 1999.

Plant dry weight declined 45\% from 18 Nov. 1999 to 17 Feb. 2000. This may have been a result of leaf senescence between sampling dates. Plant dry weight increased an average of $125 \%$ from 17 Feb. to 1 June 2000 (Fig. 1). In 2001, plant dry weight changed little from spring through harvest in the measured treatments 1 , 3, and 7-9 (Table 1), and was not affected by FN treatment (data not shown), a reflection of the large variability in the data as the planting entered its third fruiting season.

Plant dry weight decreased as the planting aged, from $280 \mathrm{~g} / \mathrm{plant}$ in 1999 to $161 \mathrm{~g} /$ plant in 2000 to $73 \mathrm{~g} /$ plant in 2001 .

There was no FN treatment effect on dry weight partitioning to individual plant parts (roots, crown, inflorescences, leaves, runners, or fruit) on most of the sample dates in the first through third fruiting seasons (data not shown). After renovation (1 July 1999), there were no significant differences between treatment $1\left(28 \mathrm{~kg} \cdot \mathrm{ha}^{-1}\right.$ of $\mathrm{N}$ in spring) and treatment 3 (foliar urea application at the pre-bloom 


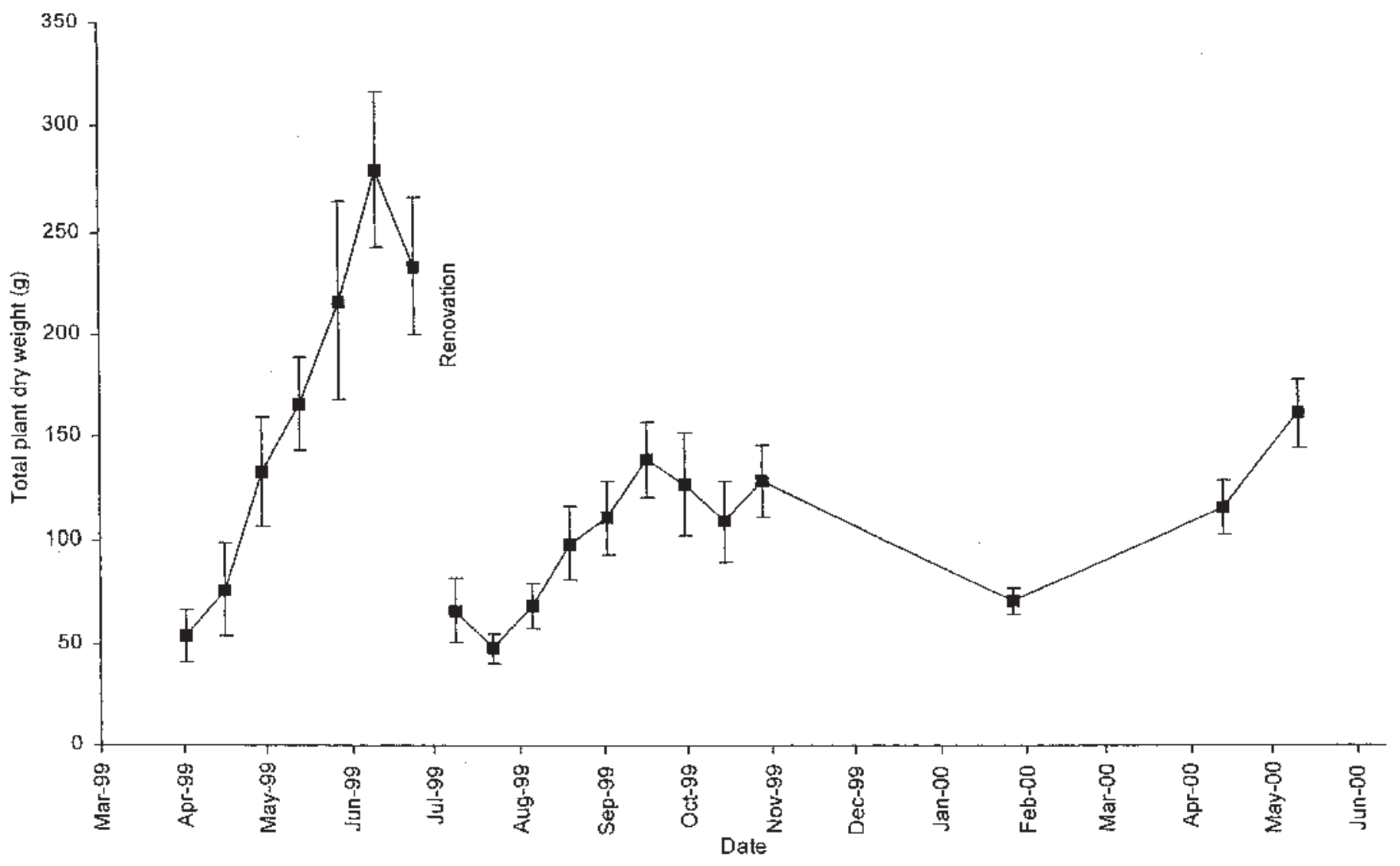

Fig. 1. Changes in total plant dry weight from Spring 1999 through Spring 2000 in 'Totem', June-bearing strawberry. Points are mean of fertilizer treatments 1 through 6 (Table 1) $\pm \mathrm{SE}, \mathrm{n}=3$. Dates listed on the $\mathrm{x}$ axis correspond to the midpoint of each month.

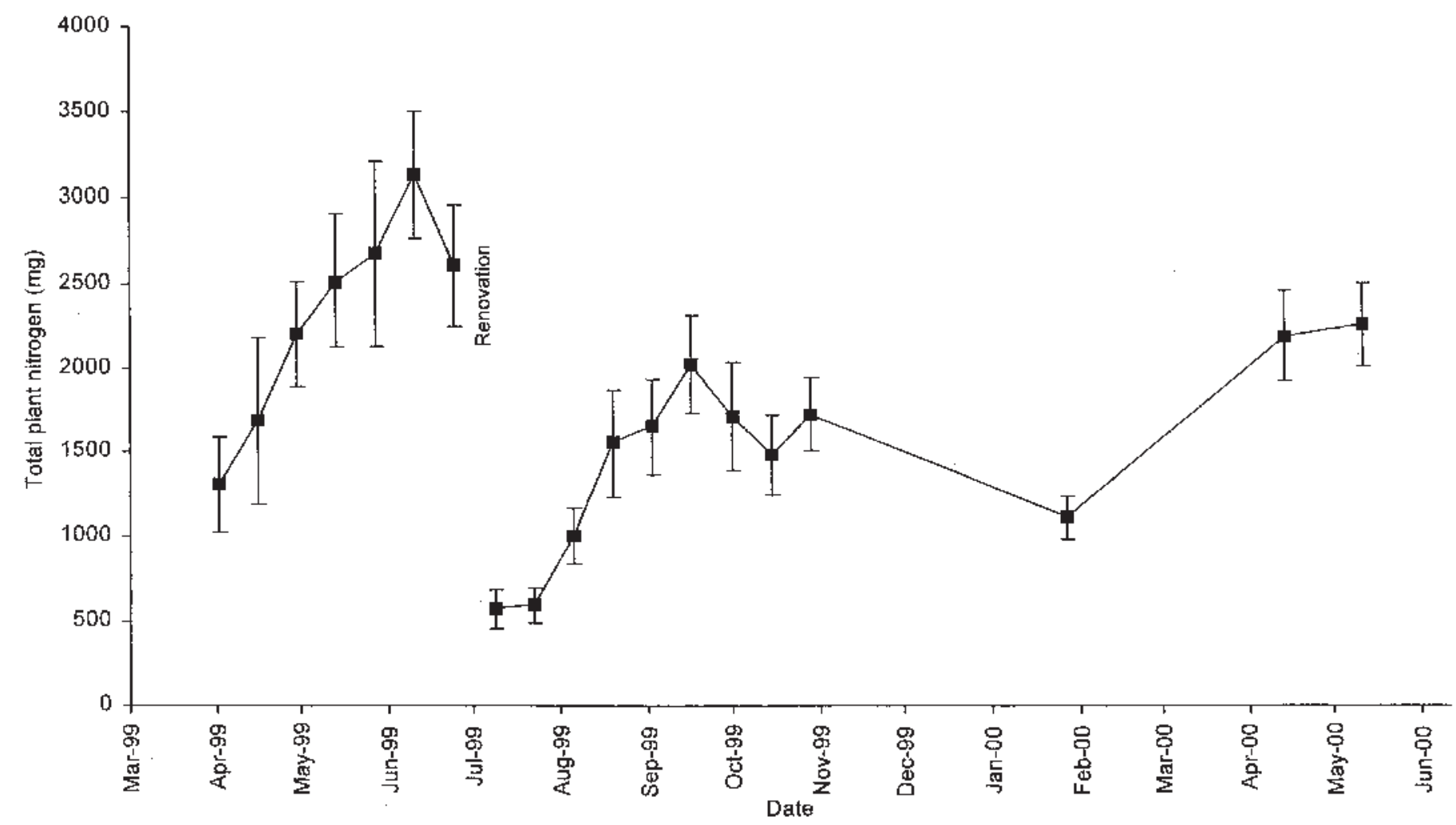

Fig. 2. Changes in total plant nitrogen content from Spring 1999 through Spring 2000 in 'Totem', June-bearing strawberry. Points are mean of fertilizer treatments 1 through 6 (Table 1) $\pm \mathrm{SE}, \mathrm{n}=3$. Dates listed on the $\mathrm{x}$ axis correspond to the midpoint of each month. 
stage) in the partitioning of dry matter. Both treatments averaged $55 \%, 11 \%, 9 \%, 9 \%$, and $8 \%$ dry matter in leaves, crown, fruit, runners and roots, respectively. At the beginning of dormancy (4 Nov. 1999), there was no FN treatment effect on dry matter partitioning with plants averaging $40 \%, 30 \%, 10 \%$, and $20 \%$ of total plant dry matter in leaves, crown, runners and roots, respectively.

Partitioning of total plant dry matter also changed with planting age. Percentage of dry matter in the crown increased from $12 \%$ in the first fruiting season to $25 \%$ in the second and $48 \%$ in the third fruiting season. In contrast, the percentage of dry matter in leaves declined from $58 \%$ in the first fruiting season to $16 \%$ in the third fruiting season.

Nitrogen ACCUMUlation. Total plant $\mathrm{N}$ was significantly affected by FN treatment $(P<0.05)$ only on 21 Oct. 1999 when the plants fertilized with an additional foliar application on either 11 Aug. or 8 Sept. 1999 (treatments 5 and 6) had a lower total plant N than treatments 1 through 4 (Table 1 ). Thus, data were pooled for treatments 1 through 6 . Changes in total plant $\mathrm{N}$ paralleled those seen in total plant dry weight (Fig. 2).

Total plant $\mathrm{N}$ increased from an average of 1306 to $2669 \mathrm{mg}$ / plant from 22 Apr to 17 June 1999, midfruit harvest (Fig. 2) - an increase of $\approx 35 \mathrm{~kg} \cdot \mathrm{ha}^{-1}$ of $\mathrm{N}$. Based on total yield per treatment (not all fruit harvested are presented in Fig. 2), nitrogen lost during harvest averaged $30 \mathrm{~kg} \cdot \mathrm{ha}^{-1}$. At renovation an average of $2033 \mathrm{mg} /$ plant of $\mathrm{N}$, or $\approx 52 \mathrm{~kg} \cdot \mathrm{ha}^{-1}$ was removed when leaves were mowed (Fig. 2). Total plant $\mathrm{N}$ increased to an average of $1723 \mathrm{mg} / \mathrm{plant}$ (44 kg.ha ${ }^{-1}$ of $\mathrm{N}$ ) before plants entered dormancy in 1999 (Fig. 2 ), an increase of $\approx 30 \mathrm{~kg} \cdot \mathrm{ha}^{-1}$ of $\mathrm{N}$ from the time of renovation. Since a large amount of $\mathrm{N}$ is taken up and then removed, the net $\mathrm{N}$ requirements for the first fruiting season were estimated at only $40 \mathrm{~kg} \cdot \mathrm{ha}^{-1} ; 10 \mathrm{~kg} \cdot \mathrm{ha}^{-1}$ for plant growth (difference between season start and end) and $30 \mathrm{~kg} \cdot \mathrm{ha}^{-1}$ (average) for fruit production. Average total plant $\mathrm{N}$ in late May/early June decreased from the first (3135 $\mathrm{mg} /$ plant) to the third ( $866 \mathrm{mg} /$ plant) fruiting season.

At the beginning of the third fruiting season (28 Jan. 2001), plants that had not received any FN since renovation in 1999 (treatment 8, Table 1) had less total plant $\mathrm{N}$ than plants fertilized with $55 \mathrm{~kg} \cdot \mathrm{ha}^{-1}$ of $\mathrm{N}$ at renovation (treatment 7) or a late-season foliar application in 2000 (treatment 9; Table 2). However, just before fruit harvest on 31 May 2001, plants that had not received any FN since renovation in 1999 (treatment 8) did not differ significantly in total plant $\mathrm{N}$ (924 $\mathrm{mg} /$ plant) than plants that received $55 \mathrm{~kg} \cdot \mathrm{ha}^{-1}$ of $\mathrm{N}$ at renovation (treatment $7 ; 1372 \mathrm{mg} / \mathrm{plant}$ ) or a foliar urea application on 17 Oct. in 2000 (treatment 9; $1131 \mathrm{mg} /$ plant).

Total $\mathrm{N}$ in individual strawberry plant parts was not significantly affected by FN treatment on most of the sampling dates in the first through third fruiting seasons (data not shown). During fruiting in 1999 , all treatments averaged $32 \%, 52 \%, 8 \%$, and $4 \%$ of the total plant $\mathrm{N}$ in the reproductive tissues, leaves, crown, and roots, respectively. On 18 Nov. 1999, there was no FN treatment effect on partitioning of total $\mathrm{N}$ with plants averaging $47 \%, 29 \%, 19 \%$, and $5 \%$ of total plant $\mathrm{N}$ in crowns, roots, runners, and leaves, respectively.

Nitrogen concentration of individual plant parts was not significantly affected by FN treatment throughout the first through third fruiting season (data not shown). On 3 June 1999, before renovation, the average $\mathrm{N}$ concentration (\%) was $1.01,1.24,1.62,1.31$, and 1.64 for roots, crown, leaves, truss, and green fruit, respectively. On 12 Aug. 1999, percent $\mathrm{N}$ of leaves ranged from 2.58 to 2.94, within the recommended $2.5 \%$ to $3.0 \%$ after renovation (Hart et al., 2000), with no FN treatment effect. Concentration of $\mathrm{N}$ in leaves was lower in the spring or during fruiting, 1.35 to $1.69 \%$.

\section{Nitrogen derived from fertilizer}

SEASON OF FERTILIZER APPLICATION. Following granular fertilization of strawberry plants on 21 Apr 1999 (treatment 1), the percentage of the $\mathrm{N}$ that was derived from the fertilizer (\%NDFF) increased to $20 \%$ (682 $\mathrm{mg}{ }^{15} \mathrm{~N} /$ plant) just before fruit harvest, declined during fruit harvest and then was reduced dramatically as leaves were mowed during renovation (Fig. 3). Following foliar fertilization in spring (treatments 3 and 4) the percent NDFF increased to $\approx 10 \%$ (277 mg ${ }^{15} \mathrm{~N} /$ plant) and remained at this level until renovation. The percent NDFF in these treatments continued to decline after renovation as new uptake of unlabeled $\mathrm{N}$ diluted the labeled $\mathrm{N}$ present in the plants. Plants receiving the early and late foliar postrenovation $\mathrm{N}$ application in 1999 (treatments 5 and 6) had $\approx 5 \%$ to $10 \% \mathrm{NDFF}$ ( $\approx 89 \mathrm{mg}{ }^{15} \mathrm{~N} /$ plant) shortly after the application but this percentage then declined due to dilution of

Table 2. The effect of nitrogen fertilization rate and method on fertilizer uptake or use efficiency and total plant nitrogen in 'Totem' strawberry at time of maximum fertilizer uptake and before growth started the following season.

\begin{tabular}{|c|c|c|c|}
\hline \multirow[b]{2}{*}{ Treatment ${ }^{z}$} & \multicolumn{2}{|c|}{ Fertilizer use efficiencyy (\%) } & \multirow{2}{*}{$\begin{array}{l}\text { Total N (mg/plant) } \\
\text { At start of growth } \\
\text { following yearx }\end{array}$} \\
\hline & $\begin{array}{c}\text { At } \\
\text { maximum }^{x}\end{array}$ & $\begin{array}{l}\text { At start of growth } \\
\text { following yearx }\end{array}$ & \\
\hline 1) $28 \mathrm{~kg} \cdot \mathrm{ha}^{-1} \mathrm{~N}$, April 1999 & $62.6 \pm 6.6^{\mathrm{w}}$ & $2.9 \pm 1.1$ & $1124 \pm 198$ \\
\hline 2) $55 \mathrm{~kg} \cdot \mathrm{ha}^{-1} \mathrm{~N}$, July 1999 & $42.0 \pm 5.4$ & $20.0 \pm 3.9$ & $1065 \pm 54$ \\
\hline 3) Foliar urea, April 1999 & $46.1 \pm 11.1$ & $1.3 \pm 0.4$ & $1228 \pm 231$ \\
\hline 4) Foliar urea, June 1999 & $52.4 \pm 6.9$ & $0.6 \pm 0.6$ & $1062 \pm 70$ \\
\hline 5) Foliar urea, August 1999 & $14.8 \pm 1.7$ & $7.3 \pm 0.6$ & $974 \pm 130$ \\
\hline 6) Foliar urea, September 1999 & $16.8 \pm 1.6$ & $13.4 \pm 1.9$ & $1170 \pm 54$ \\
\hline 7) $55 \mathrm{~kg} \cdot \mathrm{ha}^{-1} \mathrm{~N}$, July 2000 & NA & $16.3 \pm 2.7$ & $1170 \pm 86$ \\
\hline 8) No fertilizer in 2000 & NA & NA & $646 \pm 60$ \\
\hline 9) Foliar urea, October 2000 & NA & $26.2 \pm 5.0$ & $1120 \pm 255$ \\
\hline
\end{tabular}

${ }^{2}$ Refer to corresponding treatment number in Table 1 for more information and date of ${ }^{15} \mathrm{~N}$ application. All treatments received $55 \mathrm{~kg} \cdot$ ha ${ }^{-1}$ of $\mathrm{N}$ in the planting year, 1998 and at renovation (28 July 1999). Granular applications were applied as ammonium nitrate in a broadcast band to the matted row. Foliar applications were a $5 \%$ urea solution in $700 \mathrm{~L} \cdot \mathrm{ha}^{-1}$ of water $\left(23 \mathrm{~g} \cdot \mathrm{L}^{-1} \mathrm{of} \mathrm{N}\right)$ to the treatment plot, a commercial rate and volume. y Fertilizer use efficiency $($ FUE $)=\left(\right.$ quantity of ${ }^{15} \mathrm{~N}$ present in the whole strawberry plant at the time indicated/total ${ }^{15} \mathrm{~N}$ applied in the fertilizer) $\times 100$. xThe time of maximum fertilizer uptake (maximum quantity of ${ }^{15} \mathrm{~N}$ in the plant varied by treatment as follows: 1) 17 June $1999 ; 2$ ) 18 Nov. 1999; 3) 15 July 1999; 4) 1 July 1999; 5) 9 Sept. 1999; 6) 21 Oct. 1999; 7 and 9) NA = not available as plants were not destructively harvested until the following late winter; and 8) NA as no ${ }^{15} \mathrm{~N}$ was applied. Dates for the start of growth the following year were 1-6) $17 \mathrm{Feb}$. 2000 and $7-9$ ) 28 Jan. 2001.

wValues are the mean $\pm \operatorname{SE}(n=3)$. 


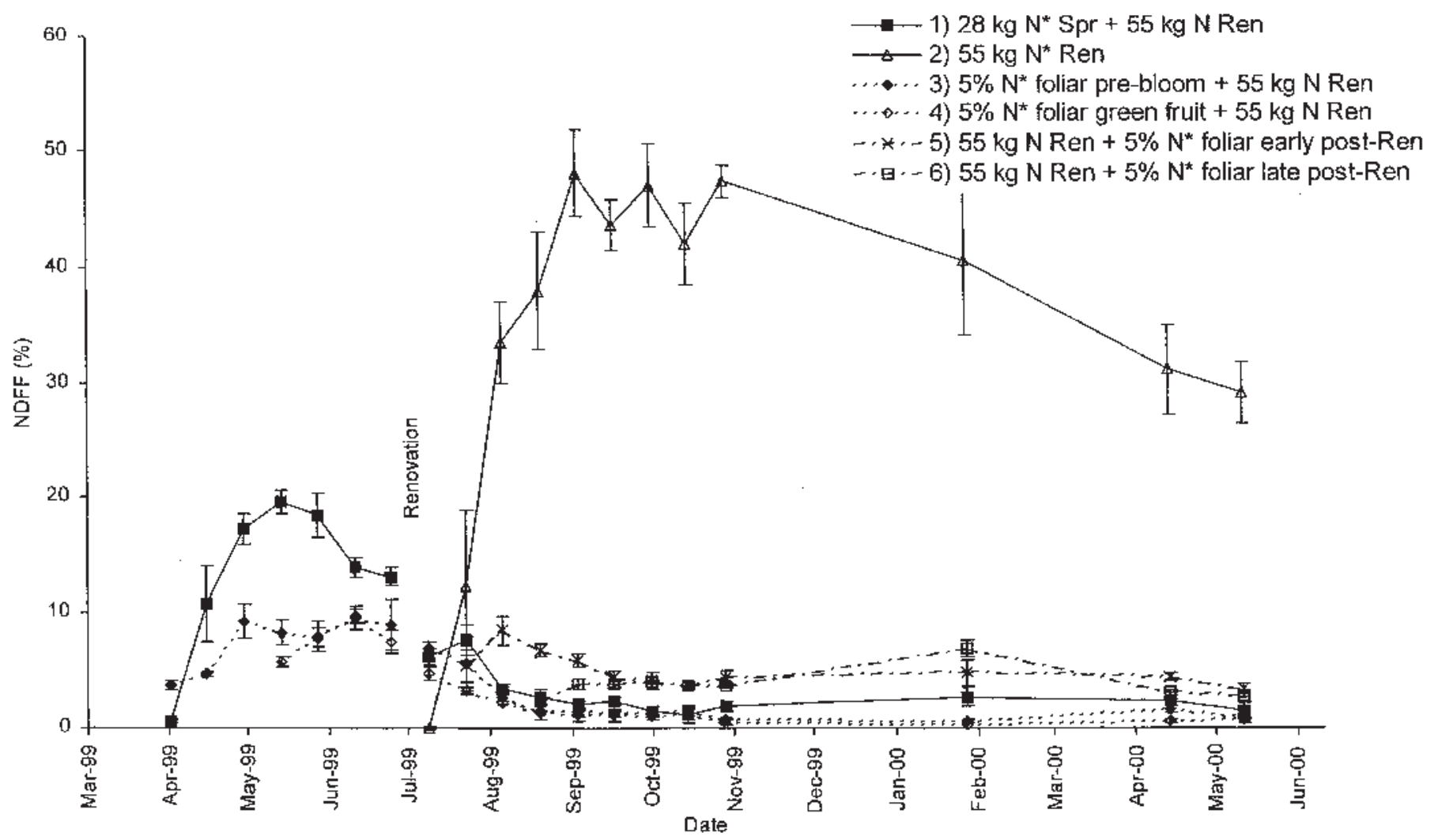

Fig. 3. The influence of $\mathrm{N}$ fertilization treatments on percent nitrogen derived from the fertilizer (NDFF) from Spring 1999 through Spring 2000 in 'Totem', Junebearing strawberry. Points are mean $\pm \mathrm{SE}, \mathrm{n}=3$. Dates listed on the $\mathrm{x}$ axis correspond to the midpoint of each month. Treatment numbers in legend correspond to those in Table 1. Application of ${ }^{15} \mathrm{~N}$ is indicated in legend with an asterisk.

labeled $\mathrm{N}$ by new uptake. The NDFF of plants that were treated with a foliar fertilizer after renovation in 1999 (treatments 5 and 6) was $5 \%$ to $7 \%$ on 17 Feb. 2000 (Fig. 3). Maximum NDFF for the foliar urea applied 17 Oct. 2000 (treatment 9) was $15 \%$ on 28 Jan. 2001; plants were not sampled between 17 Oct. 2000 and 28 Jan. 2001

In contrast, plants fertilized with $55 \mathrm{~kg} \cdot \mathrm{ha}^{-1}$ of $\mathrm{N}$ at renovation (treatment 2) showed a rapid increase in percent NDFF to a maxi- mum of $48 \%$ (917mg ${ }^{15} \mathrm{~N} /$ plant) just before dormancy (Fig. 3). The percent NDFF in this treatment declined over the dormant season (18 Nov. 1999 to 17 Feb. 2000). This decline was most likely due to leaf senescence in winter as the mass of leaves and NDFF in the same time period declined by $\approx 80 \%$ and $84 \%$, respectively (data not shown).

In Spring 1999, there was little effect of spring fertilization method or rate on partitioning of new FN during fruiting (Table 3).

Table 3. The proportion of fertilizer nitrogen $\left({ }^{15} \mathrm{~N}\right)$ partitioned to 'Totem' strawberry plant parts in the fruiting season and just before leaf senescence in the year of fertilization (first fruiting season, 1999) as affected by rate, method, and timing of fertilization.

\begin{tabular}{|c|c|c|c|c|c|c|c|}
\hline \multirow[b]{2}{*}{ Time and treatment ${ }^{2}$} & \multicolumn{7}{|c|}{ Percentage of ${ }^{15} \mathrm{~N}$ in plant part (\% of total in whole plant) } \\
\hline & Roots & Crown & Leaves & Inflorescence & Green fruit & Red fruit & Runners \\
\hline \multicolumn{8}{|c|}{ During fruiting (17 june 1999) } \\
\hline 1) $28 \mathrm{~kg} \cdot \mathrm{ha}^{-1} \mathrm{~N}$, Apr. & 1.3 & 2.9 & 56.1 & $9.6 \mathrm{a}^{\mathrm{x}}$ & 15.8 & 11.3 & 2.9 \\
\hline 3) Foliar urea, Apr. & 2.7 & 4.1 & 57.7 & $5.8 \mathrm{ab}$ & 9.4 & 15.8 & 4.6 \\
\hline 4) Foliar urea, June & 1.9 & 2.0 & 37.0 & $3.0 \mathrm{~b}$ & 33.2 & 18.9 & 4.0 \\
\hline Significance $(P \text { value })^{y}$ & 0.13 & 0.076 & 0.33 & 0.048 & 0.39 & 0.56 & 0.75 \\
\hline \multicolumn{8}{|l|}{ Late in the fall (18 Nov. 1999) } \\
\hline 1) $28 \mathrm{~kg} \cdot \mathrm{ha}^{-1} \mathrm{~N}$, Apr. & $24.5 \mathrm{ab}$ & $44.4 \mathrm{a}$ & $27.6 \mathrm{a}$ & --- & --- & --- & $3.6 \mathrm{ac}$ \\
\hline 2) $55 \mathrm{~kg} \cdot \mathrm{ha}^{-1} \mathrm{~N}$, July & $10.9 \mathrm{~d}$ & $27.9 \mathrm{~b}$ & $49.1 \mathrm{c}$ & --- & --- & --- & $12.1 \mathrm{~b}$ \\
\hline 3) Foliar urea, Apr. & $35.1 \mathrm{ac}$ & $50.1 \mathrm{a}$ & $14.7 \mathrm{ab}$ & --- & --- & --- & $0.1 \mathrm{~d}$ \\
\hline 4) Foliar urea, June & $45.1 \mathrm{c}$ & $46.0 \mathrm{a}$ & $7.3 \mathrm{~b}$ & --- & --- & --- & $1.6 \mathrm{~cd}$ \\
\hline 5) Foliar urea, Aug. & $18.7 \mathrm{bd}$ & $29.6 \mathrm{~b}$ & $47.8 \mathrm{c}$ & --- & --- & --- & $3.9 \mathrm{ac}$ \\
\hline 6) Foliar urea, Sept. & $16.1 \mathrm{bd}$ & $25.9 \mathrm{~b}$ & $52.3 \mathrm{c}$ & --- & --- & --- & $5.7 \mathrm{a}$ \\
\hline Significance $(P \text { value })^{\mathrm{y}}$ & 0.0019 & 0.013 & 0.0001 & --- & --- & --- & 0.0002 \\
\hline
\end{tabular}

${ }^{2}$ Refer to corresponding treatment number in Table 1 for more information and date of ${ }^{15} \mathrm{~N}$ application. All treatments received $55 \mathrm{~kg} \cdot \mathrm{ha}{ }^{-1} \mathrm{of} \mathrm{N}^{\mathrm{N}}$ in the planting year, 1998 and at renovation (28 July 1999). Granular applications were applied as ammonium nitrate in a broadcast band to the matted row. Foliar applications were a $5 \%$ urea solution in $700 \mathrm{~L} \cdot \mathrm{ha}^{-1}$ of water $\left(23 \mathrm{~g} \cdot \mathrm{L}^{-1}\right.$ of N$)$ to the treatment plot, a commercial rate and volume.

${ }^{y}$ Significance $(P)$ is for within time analyses only.

xMeans followed by the same letter within time are not significantly different $(P>0.05)$. 
Plants that were fertilized with $28 \mathrm{~kg} \cdot \mathrm{ha}^{-1}$ of ${ }^{15} \mathrm{~N}$ in April (treatment 1) did have more FN partitioned to the inflorescences $(10 \%$ of FN in the plant) than plants that received foliar urea on 2 June 1999 (treatment 4; Table 3).

On 18 Nov. 1999, just before dormancy, plants that were fertilized with $55 \mathrm{~kg} \cdot \mathrm{ha}^{-1}$ of ${ }^{15} \mathrm{~N}$ at renovation 28 July 1999 (treatment 2) had more of this $\mathrm{FN}$ in the leaves and runners and less in the roots and crown than plants fertilized on 21 Apr. 1999 (treatment 1; Table 3). Most of the small amount of remaining $\mathrm{FN}$ in spring fertilized treatments (Fig. 3) was partitioned to the crown and roots in Nov. 1999 (Table 3).

Recovery of FN or fertilizer use efficiency (FUE) was estimated at $63 \%$ for the $28 \mathrm{~kg} \cdot \mathrm{ha}^{-1}$ of $\mathrm{N}$ applied on $21 \mathrm{Apr}$. (treatment 1) and $42 \%$ for the $55 \mathrm{~kg} \cdot \mathrm{ha}^{-1}$ of $\mathrm{N}$ applied at renovation (treatment 2 ), based on the total quantity of labeled granular fertilizer applied and the maximum accumulation of ${ }^{15} \mathrm{~N}$ (Table 2). The FUE for the foliar fertilizers (treatments 3-6) ranged from $15 \%$ to $52 \%$. The accumulation of NDFF in the foliar FN treatments increased well after the foliar fertilizer was applied (Fig. 3), indicating that most of the uptake was through the roots rather than the leaves.
SEASON AFTER FERTILIZER APPLICATION. Less than 0.01\% NDFF was measured in barley grown in 2000 , following strawberry plants that had received as much as $55 \mathrm{~kg} \cdot \mathrm{ha}^{-1}$ of ${ }^{15} \mathrm{~N}$ depleted fertilizer at renovation in 1999. Barley grown on soil that had not received ${ }^{15} \mathrm{~N}$ depleted fertilizer in 1999 or 2000 had $<0.01 \%$ NDFF. It was therefore assumed for the purposes of this study that the quantity of ${ }^{15} \mathrm{~N}$-depleted fertilizer applied in 1999 that was supplied to strawberry plants from the soil in 2000 was negligible. Consequently, it is also assumed that all the NDFF present in plants in 2000 was attributed to uptake of NDFF during 1999.

The percent NDFF in all treatments declined during Spring 2000 as ${ }^{15} \mathrm{~N}$ was being diluted by new uptake (Fig. 3). In June 2000, the percent NDFF in the spring (1999) applied fertilizer treatments (1, 3 and 4 ) was low at $1.5 \%$ and $<1 \%$ for the ground and foliar urea applications, respectively. The late season (1999) foliar applications (treatments 5 and 6) had a greater NDFF than the early season applications, but the percentage was still low $(\approx 5 \%)$ on 1 June 2000 (Fig. 3). The percentage of NDFF for plants that received $55 \mathrm{~kg} \cdot \mathrm{ha}^{-1}$ of ${ }^{15} \mathrm{~N}$ applied at renovation in 1999 (treatment 2) was relatively high (Fig. 3) and the mass of NDFF was higher

Table 4. The proportion of reserve fertilizer nitrogen $\left({ }^{15} \mathrm{~N}\right)$ partitioned to 'Totem' strawberry plant parts in the second (2000) and third (2001) fruiting seasons as affected by rate, method, and timing of fertilization in 1999.

\begin{tabular}{|c|c|c|c|c|c|}
\hline \multirow[b]{2}{*}{ Time and treatment ${ }^{2}$} & \multicolumn{5}{|c|}{ Percentage of ${ }^{15} \mathrm{~N}$ in plant part (\% of total in whole plant) } \\
\hline & Roots & Crown & Leaves & Inflorescence & Green fruit \\
\hline \multicolumn{6}{|l|}{ Second fruiting season } \\
\hline \multicolumn{6}{|l|}{ Before growth (17 Feb. 2000) } \\
\hline 1) $28 \mathrm{~kg} \cdot \mathrm{ha}^{-1} \mathrm{~N}$, April & 36.5 & 57.7 & 5.8 & --- & --- \\
\hline 2) $55 \mathrm{~kg} \cdot \mathrm{ha}^{-1} \mathrm{~N}$, July & 36.4 & 46.4 & 17.2 & --- & --- \\
\hline 3) Foliar urea, April & 40.2 & 45.5 & 14.3 & --- & --- \\
\hline 4) Foliar urea, June & 68.4 & 31.3 & 0.3 & --- & --- \\
\hline 5) Foliar urea, August & 34.2 & 49.2 & 16.6 & --- & --- \\
\hline 6) Foliar urea, September & 33.2 & 52.1 & 14.7 & --- & --- \\
\hline Significance $(P)^{\mathrm{y}}$ & 0.073 & 0.28 & 0.27 & --- & --- \\
\hline \multicolumn{6}{|l|}{ Before fruiting (1 June 2000) } \\
\hline 1) $28 \mathrm{~kg} \cdot \mathrm{ha}^{-1} \mathrm{~N}$, April & $20.1 \mathrm{a}^{\mathrm{x}}$ & $35.5 \mathrm{a}$ & $28.4 \mathrm{a}$ & $6.0 \mathrm{a}$ & 9.9 \\
\hline 2) $55 \mathrm{~kg} \cdot \mathrm{ha}^{-1} \mathrm{~N}$, July & $5.7 \mathrm{~b}$ & $19.5 \mathrm{c}$ & $52.5 \mathrm{~b}$ & $7.7 \mathrm{ab}$ & 14.6 \\
\hline 3) Foliar urea, April & $18.2 \mathrm{a}$ & $27.5 \mathrm{~b}$ & $40.8 \mathrm{ab}$ & $5.1 \mathrm{a}$ & 8.5 \\
\hline 4) Foliar urea, June & $18.0 \mathrm{a}$ & $34.1 \mathrm{ab}$ & $32.2 \mathrm{a}$ & $5.0 \mathrm{a}$ & 10.7 \\
\hline 5) Foliar urea, August & $10.4 \mathrm{~b}$ & $16.0 \mathrm{c}$ & $53.4 \mathrm{~b}$ & $9.8 \mathrm{~b}$ & 10.4 \\
\hline 6) Foliar urea, September & $9.9 \mathrm{~b}$ & $15.3 \mathrm{c}$ & $53.4 \mathrm{~b}$ & $7.4 \mathrm{ab}$ & 13.9 \\
\hline Significance $(P)^{\mathrm{y}}$ & 0.0053 & 0.0002 & 0.0038 & 0.018 & 0.54 \\
\hline \multicolumn{6}{|l|}{ Third fruiting season } \\
\hline \multicolumn{6}{|l|}{ Before growth (28 Jan. 2001) } \\
\hline 1) $28 \mathrm{~kg} \cdot \mathrm{ha}^{-1} \mathrm{~N}$, April & 26.0 & 67.0 & $7.0 \mathrm{a}$ & --- & --- \\
\hline 2) $55 \mathrm{~kg} \cdot \mathrm{ha}^{-1} \mathrm{~N}$, July & 29.0 & 59.3 & $11.7 \mathrm{a}$ & --- & --- \\
\hline 3) Foliar urea, April & 30.6 & 63.5 & $5.9 \mathrm{a}$ & --- & --- \\
\hline 7) $55 \mathrm{~kg} \cdot \mathrm{ha}^{-1} \mathrm{~N}$, July & 25.3 & 46.9 & $27.7 \mathrm{~b}$ & --- & --- \\
\hline 9) Foliar urea, October & 28.4 & 48.0 & $23.6 \mathrm{~b}$ & --- & --- \\
\hline Significance $(P)^{\mathrm{y}}$ & 0.75 & 0.086 & 0.0022 & --- & --- \\
\hline \multicolumn{6}{|l|}{ Before fruiting (31 May 2001) } \\
\hline 1) $28 \mathrm{~kg} \cdot \mathrm{ha}^{-1} \mathrm{~N}$, April & $18.5 \mathrm{ab}$ & $59.1 \mathrm{ab}$ & $12.7 \mathrm{ab}$ & $1.6 \mathrm{a}$ & $8.1 \mathrm{a}$ \\
\hline 2) $55 \mathrm{~kg} \cdot \mathrm{ha}^{-1} \mathrm{~N}$, July & $8.2 \mathrm{bc}$ & $41.4 \mathrm{~b}$ & $22.8 \mathrm{ac}$ & $7.0 \mathrm{~b}$ & $20.6 \mathrm{~b}$ \\
\hline 3) Foliar urea, April & $27.2 \mathrm{a}$ & $63.7 \mathrm{a}$ & $3.6 \mathrm{~b}$ & $1.1 \mathrm{a}$ & $4.4 \mathrm{a}$ \\
\hline 7) $55 \mathrm{~kg} \cdot \mathrm{ha}^{-1} \mathrm{~N}$, July & $1.9 \mathrm{c}$ & $20.5 \mathrm{c}$ & $43.1 \mathrm{~d}$ & $11.0 \mathrm{~b}$ & $23.6 \mathrm{~b}$ \\
\hline 9) Foliar urea, October & $1.0 \mathrm{c}$ & $18.3 \mathrm{c}$ & $37.5 \mathrm{dc}$ & $11.2 \mathrm{~b}$ & $31.9 \mathrm{c}$ \\
\hline Significance $(P)^{\mathrm{y}}$ & 0.0051 & 0.0026 & 0.0029 & 0.0015 & 0.003 \\
\hline
\end{tabular}

${ }^{2}$ Refer to corresponding treatment number in Table 1 for more information on when ${ }^{15} \mathrm{~N}$ was applied. All treatments received $55 \mathrm{~kg} \cdot \mathrm{ha}^{-1}$ of $\mathrm{N}$ in the planting year, 1998 and at renovation (28 July 1999). Granular applications were applied as ammonium nitrate in a broadcast band to the matted row. Foliar applications were a $5 \%$ urea solution in $700 \mathrm{~L} \cdot \mathrm{ha}^{-1}$ of water $\left(23 \mathrm{~g} \cdot \mathrm{L}^{-1}\right.$ of $\left.\mathrm{N}\right)$ to the treatment plot, a commercial rate and volume. y Significance $(P)$ is for within time analyses only.

xMeans followed by the same letter within time and fruiting season are not significantly different $(P>0.05)$. 
Table 5. The effect of nitrogen fertilization treatment on yield and fruit quality of 'Totem' strawberry from 1999 (the first fruiting season) through the third fruiting season.

\begin{tabular}{|c|c|c|c|c|c|}
\hline Treatment ${ }^{z}$ & $\begin{array}{c}\text { Yield } \\
\text { (kg/plot) }\end{array}$ & $\begin{array}{c}\text { Berry } \\
\text { wt } \\
(\mathrm{g})\end{array}$ & $\begin{array}{c}\text { Soluble } \\
\text { solids } \\
(\%)\end{array}$ & $\begin{array}{c}\text { Fruit } \\
\text { firmness }\end{array}$ & $\begin{array}{l}\text { Rotted } \\
\text { fruit } \\
(\%)\end{array}$ \\
\hline \multicolumn{6}{|l|}{1999} \\
\hline 1) $28 \mathrm{~kg} \cdot \mathrm{ha}^{-1} \mathrm{~N}$, April 1999 & 9.2 & 14.4 & 9.5 & 149 & 11.9 \\
\hline 2) $55 \mathrm{~kg} \cdot \mathrm{ha}^{-1} \mathrm{~N}$, July 1999 & 5.8 & 13.8 & 9.9 & 156 & 15.3 \\
\hline 3) Foliar urea, April 1999 & 6.9 & 14.3 & 9.9 & 154 & 21.6 \\
\hline 4) Foliar urea, June 1999 & 7.7 & 12.9 & 9.3 & 153 & 11.3 \\
\hline Significance $(P)^{\mathrm{y}}$ & 0.055 & 0.69 & 0.43 & 0.90 & 0.097 \\
\hline \multicolumn{6}{|l|}{2000} \\
\hline 1) $28 \mathrm{~kg} \cdot \mathrm{ha}^{-1} \mathrm{~N}$, April $1999+$ April 2000 & 2.0 & 7.4 & 10.7 & 100 & 19.5 \\
\hline 2) $55 \mathrm{~kg} \cdot \mathrm{ha}^{-1} \mathrm{~N}$, July 1999 & 3.5 & 7.8 & 9.9 & 112 & 24.8 \\
\hline 3) Foliar urea, April $1999+$ April 2000 & 3.9 & 8.5 & 9.3 & 110 & 23.2 \\
\hline 4) Foliar urea, June 1999 & 3.2 & 8.3 & 9.9 & 116 & 22.0 \\
\hline 5) Foliar urea, August 1999 & 2.7 & 8.3 & 10.1 & 118 & 22.6 \\
\hline 6) Foliar urea, September 1999 & 3.3 & 8.6 & 9.8 & 133 & 19.5 \\
\hline Significance $(P)^{\mathrm{y}}$ & 0.53 & 0.39 & 0.11 & 0.83 & 0.87 \\
\hline \multicolumn{6}{|l|}{2001} \\
\hline 1) $28 \mathrm{~kg} \cdot \mathrm{ha}^{-1} \mathrm{~N}$, April $1999+$ April 2000 & 4.0 & 5.9 & $\mathrm{NA}^{\mathrm{x}}$ & NA & 21.8 \\
\hline 2) $55 \mathrm{~kg} \cdot \mathrm{ha}^{-1} \mathrm{~N}$, July 1999 & 4.9 & 6.4 & NA & NA & 16.3 \\
\hline 3) Foliar urea, April $1999+$ April 2000 & 5.7 & 5.6 & NA & NA & 19.4 \\
\hline 7) $55 \mathrm{~kg} \cdot \mathrm{ha}^{-1} \mathrm{~N}$, July 2000 & 4.9 & 6.4 & NA & NA & 15.0 \\
\hline 9) Foliar urea, October 2000 & 5.8 & 6.8 & NA & NA & 15.0 \\
\hline Significance $(P)^{\mathrm{y}}$ & 0.26 & 0.33 & NA & NA & 0.36 \\
\hline
\end{tabular}

${ }^{2}$ Refer to corresponding treatment number in Table 1 for more information. All treatments received $55 \mathrm{~kg} \cdot \mathrm{ha}^{-1}$ of $\mathrm{N}$ in the planting year, 1998 and at renovation (28 July 1999). Granular applications were applied as ammonium nitrate in a broadcast band to the matted row. Foliar applications were a $5 \%$ urea solution in $700 \mathrm{~L} \cdot \mathrm{ha}^{-1}$ of water $\left(23 \mathrm{~g} \cdot \mathrm{L}^{-1}\right.$ of $\left.\mathrm{N}\right)$ to the treatment plot, a commercial rate and volume.

${ }^{y}$ Significance $(P)$ is for within-year analyses only.

xData on percent soluble solids and firmness were not collected in 2001.

than that of the other treatments $\left(600 \mathrm{mg}{ }^{15} \mathrm{~N} /\right.$ plant for treatment 2 compared to $<100 \mathrm{mg}{ }^{15} \mathrm{~N} /$ plant for treatments $1,3-6$, on average). About $40 \%$ of the total $\mathrm{N}$ stored in the strawberry plant on 17 Feb. 2000 was derived from the fertilizer applied at renovation the year before, but by 1 June 2000 this percentage had declined to $\approx 30 \%$ (Fig. 3 ). The percent NDFF declined by about half from one growing season to the next (Fig. 3). The percent NDFF in the plants that received $28 \mathrm{~kg} \cdot \mathrm{ha}^{-1}$ of labeled $\mathrm{N}$ in spring 1999 (treatment 1) was $1.5 \%$ on 1 June 2000 (Fig. 3) and declined to $0.8 \%$ on 31 May 2001 (data not shown).

On 17 Feb. 2000, before growth began in the second fruiting season, there was no treatment effect on the partitioning of reserve $\mathrm{N}$ from the ${ }^{15} \mathrm{~N}$-fertilizer applied in 1999 (Table 4). The partitioning of reserve $\mathrm{FN}$ averaged $41 \%$ in the roots, $47 \%$ in crowns, and $12 \%$ in leaves.

Just before fruiting however, treatments differed in how the reserve FN was partitioned (Table 4). Plants that received FN before renovation in Spring 1999 (treatments 1, 3 and 4) differed little in how reserve FN was partitioned with about half of the reserve FN partitioned to new growth (new leaves, inflorescences, and green fruit), averaging $19 \%$ in roots, $32 \%$ in crowns, $34 \%$ in leaves, $5 \%$ in inflorescences, and $10 \%$ in green fruit (Table 4). In contrast, plants fertilized after renovation in 1999 (treatments 2, 5, and 6) partitioned $\approx 75 \%$ of the reserve FN to new growth and had less of the reserve $\mathrm{FN}$ partitioned to roots and crowns before fruiting in 2000 (Table 4).

On 28 Jan. 2001, before growth began in the third fruiting season, there was no treatment effect on how reserve $\mathrm{FN}$ was partitioned to roots and crowns (Table 4). However, plants fertilized 2 years prior (treatments 1-3) had less reserve FN partitioned to leaves than treatments fertilized 1 year prior (treatments 7 and 9; Table 4). On 31 May 2001, plants fertilized after renovation the year before (treatments 7 and 9 ) partitioned $\approx 80 \%$ of the reserve FN to new growth (Table 4). Of the reserve FN remaining in the plant from ${ }^{15} \mathrm{~N}$ applied at renovation in 1999 (treatment 2 ), $\approx 50 \%$ was partitioned to new growth on 31 May 2001 (Table 4). In treatments fertilized with ${ }^{15} \mathrm{~N}$ in Spring 1999 (treatments 1 and 3), only 10\% to $22 \%$ of the remaining $\mathrm{FN}$ was partitioned to new growth two years later (31 May 2001; Table 4).

YIELD AND FRUIT QUALITY. Fertilizer N before harvest had no significant effect on yield or berry weight in the first, second or third fruiting seasons (Table 5). There was a trend for the $28 \mathrm{~kg} \cdot \mathrm{ha}^{-1}$ of $\mathrm{N}$ in April (treatment 1) to increase yield in the first fruiting season, but this was not repeated in subsequent years. Yield was low in the second fruiting season because of frost damage to blossoms (Table 5 ). There was a trend for the foliar urea FN application pre-bloom (treatment 3 ) to increase percentage of fruit rot, but only in the first fruiting season. Fertilizer $\mathrm{N}$ treatment had no effect on percentage of soluble solids, fresh fruit firmness (Table 5), or percentage of drip loss of frozen fruit (data not shown).

\section{Discussion}

There was a strong relationship between dry weight accumulation and total plant nitrogen and neither was altered by $\mathrm{FN}$ treatment. Similar results have been reported elsewhere (Archbold and MacKown, 1988, 1995). Net dry matter accumulation in the first fruiting season was $2 \mathrm{t} \cdot \mathrm{ha}^{-1}$ not including the $4 \mathrm{t} \cdot \mathrm{ha}^{-1}$ of dry matter removed when leaves were mowed during the renovation process. Most $(>50 \%)$ of the dry matter was in the leaves during 
fruiting. About $20 \%$ of the dry matter was in the roots as plants entered dormancy, less than the $33 \%$ reported by Archbold and MacKown (1995).

Our estimated net $\mathrm{N}$ accumulation of $40 \mathrm{~kg} \cdot \mathrm{ha}^{-1}$ from spring to dormancy in the first fruiting season (including $30 \mathrm{~kg} \cdot \mathrm{ha}^{-1}$ in harvested fruit) is lower than the $55 \mathrm{~kg} \cdot \mathrm{ha}^{-1}$ (with $15-38 \mathrm{~kg} \cdot \mathrm{ha}^{-1}$ in the fruit) reported by Latet et al. (2002) and the $59 \mathrm{~kg} \cdot \mathrm{ha}^{-1}$ seasonal accumulation $\left(31 \mathrm{~kg} \cdot \mathrm{ha}^{-1}\right.$ in the fruit) reported by Albregts and Howard (1980). In our study, the first plant sample date was $\approx 1$ month after growth started in spring, thus underestimating dry matter and $\mathrm{N}$ accumulation. Previous studies have not measured dry matter and $\mathrm{N}$ removed at renovation in June bearers. If gains in dry weight and total plant $\mathrm{N}$ before renovation were considered, the seasonal accumulation in this study would be considerably higher (6 $\mathrm{t} \cdot \mathrm{ha}^{-1}$ of dry matter and $92 \mathrm{~kg} \cdot \mathrm{ha}^{-1}$ of $\mathrm{N}$ ).

Fertilizer $\mathrm{N}$ rate (including the unfertilized treatment 8) had no impact on seasonal $\mathrm{N}$ accumulation in our study, similar to findings for June bearing strawberry by Latet et al. (2002), but in contrast to Albregts and Howard (1980) study of an annual hill production system on plastic. The FN rates we evaluated, either as a broadcast granular or foliar application had no impact on the $\mathrm{N}$ concentration of plant parts throughout the season. The leaf percent $\mathrm{N}$ we observed during bloom (1.62) was similar to that reported by Blatt et al. (1981) and the $\mathrm{N}$ concentration in the leaves after renovation for all treatments fell within recommended levels (Hart et al., 2000).

The increase in dry matter partitioned to crowns and decrease in dry matter partitioning to leaves we observed was likely related to reduced dry weight production and yield as the strawberry planting aged.

Recovery of fertilizer $\mathrm{N}$ ranged from $42 \%$ to $63 \%$ for the broadcast granular applications and $15 \%$ to $52 \%$ for the foliar FN applications, depending on FN rate and timing. Our fertilizer recovery was similar to that reported in blackberry (Mohadjer et al., 2001; Naraguma et al., 1999), blueberry (Retamales and Hanson, 1989) and red raspberry (Rempel, 2003). However, the recovery rates in our study were considerably higher than the $6 \%$ to $32 \%$ reported by Archbold and MacKown $(1988,1995)$ in June-bearing strawberry. Differences between our study and theirs could be related to a higher initial planting density in our study $(25,822$ vs. 10,760 plants/ha), a possible higher canopy density at time of application (they thinned runners), the method of fertilizer application (broadcast granular in the matted row in our study compared to an aqueous single band near the center of the row in their study), the time of application (June or early September in their study), or the fruiting status of the planting (we applied $\mathrm{FN}$ in the fruiting season vs. the planting year in their study).

The maximum $\mathrm{FN}$ recovery of $52 \%$ from a spring foliar $\mathrm{N}$ application (treatment 4 ) in our study is similar to recovery rates reported in red raspberry (Reickenberg and Pritts, 1996) and grapefruit (Orbovic et al., 2001). Less foliar applied FN was recovered in strawberry plants when the FN was applied in late summer, most likely due to more volatilization of the urea under hot and dry conditions. We would expect a similar canopy size and distribution of leaf ages on the dates we applied foliar fertilizer in this study. The timing of FN accumulation and the partitioning of FN after foliar applications indicated that a significant portion of the $\mathrm{N}$ derived from the fertilizer came from root uptake rather than foliar uptake. We applied the maximum concentration of $\mathrm{N}$ $(5 \% \mathrm{wt} / \mathrm{v})$ without risking phytotoxicity and a standard volume of water for commercial application. If we had reduced the volume of water applied, we would have also reduced the total $\mathrm{N}$ applied $\left(16 \mathrm{~kg} \cdot \mathrm{ha}^{-1}\right.$ of $\left.\mathrm{N}\right)$ proportionately. At the time of foliar application, the matted row canopy was dense and no run off was observed. It is thus apparent that a foliar application is indeed a combination of foliar and root application. This has also been observed in red raspberry (Reickenberg and Pritts, 1996).

Nitrogen from spring applications was readily available to the plant. For example, the total plant percent NDFF at fruiting from the $28 \mathrm{~kg} \cdot \mathrm{ha}^{-1}$ of $\mathrm{N}$ application (treatment 1) was $20 \%$. However, fertilizer $\mathrm{N}$ from spring applications (granular or foliar) was predominantly partitioned to leaves $(50 \%)$ and reproductive tissues $(41 \%)$ rather than crown and roots $(5 \%)$ at the time of fruiting. A large portion of the spring applied $\mathrm{FN}$ was lost when fruit were harvested and plants renovated i.e. percent NDFF declined to values from $11 \%$ to $6 \%$ in 1999 (depending on treatment) as a result of renovation and then declined further due to dilution from newly applied, unlabeled FN at renovation. Thus, in contrast to speculation by Archbold and MacKown (1988), very little of the $\mathrm{N}$ taken up early in the season was immediately available after fruiting, because of the cultural practice of mowing off leaves during renovation; some, however, may be recycled back into the soil $\mathrm{N}$ pool.

Percent NDFF in strawberry plants following a granular 55 $\mathrm{kg} \cdot \mathrm{ha}^{-1}$ of $\mathrm{N}$ application at renovation (treatment 2 ) reached a high of $48 \%$ prior to dormancy in 1999 . However, during dormancy (November to February) there was a decline in NDFF to $40 \%$, likely a result of leaf senescence since leaves contained $50 \%$ of the FN present in the plant prior to dormancy. Archbold and MacKown (1988) observed a similar reduction in NDFF in strawberry from the planting year to the first fruiting season. Some of the leaf $\mathrm{N}$ lost during senescence may be recycled back into the soil $\mathrm{N}$ pool.

In June of the second fruiting season, $28 \%$ of $\mathrm{N}$ was derived from the granular fertilizer applied at renovation the previous season (treatment 2; 1999). This stored FN was partitioned to reproductive tissues (22\%), leaves (53\%), and crown and roots $(25 \%)$ just before fruit harvest. In contrast, Archbold and MacKown (1988, 1995) found that half of the FN applied in the planting year was partitioned to the reproductive tissues in the first fruiting season. These differences may be a result of planting age or because the plants in their study had relatively little NDFF in June (2\% to 5\%). When we applied $55 \mathrm{~kg} \cdot \mathrm{ha}^{-1}$ of $\mathrm{N}$ at renovation after the second fruiting season (2000; treatment 7), the NDFF was $30 \%$ in June of the third fruiting season with $35 \%$ of the $\mathrm{FN}$ in reproductive tissue, $43 \%$ in leaves, and $22 \%$ in roots and crowns. Fifteen percent of the NDFF in June 2001 came from older reserves (from $55 \mathrm{~kg} \cdot \mathrm{ha}^{-1}$ applied at renovation in 1999). This 2-year-old $\mathrm{N}$ was allocated to reproductive tissue (28\%), leaves $(23 \%)$, and root and crowns $(50 \%)$. Thus, early in the season, strawberry plants both remobilize recent and older reserve FN to leaves and reproductive tissues and acquire new $\mathrm{N}$ from the soil.

The uptake of FN from late-season foliar applications, postrenovation, was relatively small. The allocation of foliar applied $\mathrm{N}$ to developing flower buds may be of less benefit in this perennial plant than has been shown in other larger, woody perennials (Khemira et al., 1999; Sanchez et al., 1990; Shim et al., 1972).

Nitrogen fertilization rate or method of application had no effect on yield of 'Totem', in agreement with other studies with Junebearers in Ore. (Breen, 1979; Kirsch, 1959; Ullrich and Martin, 1987). On 31 May 2001, strawberry plants that received no fertilizer $\mathrm{N}$ at renovation in 2000 (treatment 8) had a similar total plant $\mathrm{N}$ content to those that received $55 \mathrm{~kg} \cdot \mathrm{ha}^{-1}$ of $\mathrm{N}$ applied at renovation in 2000 (treatment 7) even though the fertilized plants had 30\% $\mathrm{NDFF}$ and the recovery of fertilizer $\mathrm{N}$ was high. This suggests that the unfertilized strawberry plants took up more of the available $\mathrm{N}$ 
from the soil pool, especially in Spring 2001. A replacement of the $\mathrm{N}$ that could have come from soil sources with $\mathrm{N}$ from a fertilizer application is in agreement with observations of Blatt et al. (1981), that no fertilizer $\mathrm{N}$ is necessary on high $\mathrm{N}$ soils.

We saw no negative impact of spring FN on fruit quality, in contrast to some previous reports (Kirsch, 1959). Undesirable nitrogen fertilizer responses may depend on cultivar. When using the same spring $\mathrm{N}$ fertilization rate reported here, Ullrich and Martin (1987) found a negative impact on fruit firmness, percentage of fruit rot, and percent drip loss only in 'Benton', not in 'Totem', a relatively firmer fruited cultivar.

We saw no advantages from $\mathrm{FN}$ at the rates, timings and methods of application we studied on strawberry plant growth or yield. Our study indicates that strawberry plants will take up FN when it is available and partition newly acquired $\mathrm{N}$ to the new growth (leaves and reproductive tissues). Thus, much of the $\mathrm{N}$ taken up in early-season FN application is lost during renovation. Granular or foliar FN applied after renovation is partitioned to new growth (leaves and runners). Some nitrogen applied after renovation is remobilized from the leaves to the roots and crown in the fall, but a large portion ( $50 \%$ in our study) may be lost as leaves senesce.

Large treatment differences in FUE that are calculated at the time of maximum fertilizer uptake have little relevance to the long-term FUE. All pre-renovation fertilizer applications were inefficient in the long-term. A4-fold difference in FUE that was apparent among postrenovation treatments at the time of maximum fertilizer uptake was much smaller at the start of growth the following year.

Applying fertilizer after renovation clearly increases nutritional use efficiency and the amount of FN that is available in future years. Applying fertilizer after renovation also changes how FN is partitioned in future years. Regardless of year, timing, rate or method of application, postrenovation fertilizer treatments had $\approx 75 \%$ of the FN that was applied the prior year partitioned to new growth. For applications applied before renovation $\approx 40 \%$ to $50 \%$ of the FN that was applied the prior year was partitioned to new growth.

Strawberry plants will use reserve $\mathrm{N}$ for growth and fruiting in spring although plants will take up FN when it is applied. No advantage or disadvantage of spring or fall fertilization was observed in our study indicating that strawberries can adapt to the various sources of $\mathrm{N}$ that are available when grown on fertile soil.

\section{Literature Cited}

Albregts, E.E. and C.M. Howard. 1973. Influence of fertilizer placement and rates on strawberry production and soil fertility. Proc. Soil Crop Sci. Soc. Fla. 32:89-92.

Albregts, E.E. and C.M. Howard. 1980. Accumulation of nutrients by strawberry plants and fruit grown in annual hill culture. J. Amer. Soc. Hort. Sci. 105:386-388.

Albregts, E.E. and C.M. Howard. 1981. Effect of poultry manure on strawberry fruiting response, soil nutrient changes, and leaching. J. Amer. Soc. Hort. Sci. 106:295-298.

Albregts, E.E. and C.M. Howard. 1986. Response of strawberries to soil and foliar fertilizer rates. HortScience 21:1140-1142.

Albregts, E.E. and P. Sutton. 1971. Response of strawberry to N and K fertilization on a sandy soil. Proc. Soil Crop Sci. Soc. Fla. 31:114-116.

Archbold, D.D. and C.T. MacKown. 1988. Fate of fertilizer nitrogen in matted-row strawberry culture. Adv. Strawberry Prod. 7:32-35.

Archbold, D.D. and C.T. MacKown. 1995. Seasonal and cropping effects on total and fertilizer nitrogen use in June-bearing and day-neutral strawberries. J. Amer. Soc. Hort. Sci. 120:403-408.

Archbold, D.D. and C.T. MacKown. 1997. Nitrogen availability and fruiting influence nitrogen cycling in strawberry. J. Amer. Soc. Hort. Sci. 122:134-139.

Blatt, D.R. 1981. Effect of nitrogen source, rate and time of application on fruit yields of the Micmac strawberry. Commun. Soil Sci. Plant Anal. 12:511-518.

Bondada, B.R., J.P. Syvertsen, and L.G. Albrigo. 2001. Urea uptake by citrus leaves. HortScience 36:1061-1065.

Boynton, D. 1954. Nutrition by foliar application. Annu. Rev. Plant Physiol. 5:31-54.

Breen, P.J. 1979. The response of strawberries to nitrogen. Proc. Ore. Hort. Soc. 70:55-57.

Cutcliffe, J.A. and C.R. Blatt. 1984. Effects of N, P, K, B and lime on strawberry yields. Can. J. Plant Sci. 64:945-949.

Darrow, G.M. and G.F. Waldo. 1932. Effect of fertilizers on plant growth, yield and decay of strawberries in North Carolina. Proc. Amer. Soc. Hort. Sci. 29:318-324.

Hart, J., T. Righetti, A. Sheets, and L.W. Martin. 2000. Strawberries, fertilizer guide. Ore. State Univ. Ext. Ser. Publ. FG 14.

Hauck, R.D. and J.M. Bremner. 1976. Use of tracers for soil and fertilizer nitrogen research. Adv. Agron. 28:219-266.

Karp, K., M. Starast, and H. Kaldmäe. 2002. Influence of the age of plants and foliar fertilization on the yield of strawberry cultivar Jonsok under plastic mulch. Acta Hort. 567:459-462.

Khemira, H., T.L. Righetti, and A.N. Azarenko. 1999. Distribution of ureaderived nitrogen supplied to apple leaves. HortScience 34:1079-1081.

Kirsch, R.K. 1959. The importance of interaction effects in fertilizer and lime studies with strawberries. Proc. Amer. Soc. Hort. Sci. 73:181-188.

Latet, G., P. Meesters, and J. Bries. 2002. The influence of different nitrogen $(\mathrm{N})$ sources on the yield and leaching in open field strawberry production. Acta Hort. 567:455-458.

Miner, G.S., E.B. Poling, D.E. Carroll, and L.A. Nelson. 1997. Influence of fall nitrogen and spring nitrogen-potassium applications on yield and fruit quality of 'Chandler' strawberry. J. Amer. Soc. Hort. Sci. 122: 290-295.

Mohadjer, P., B.C. Strik, B.J. Zebarth, and T.L. Righetti. 2001. Nitrogen uptake, partitioning and remobilization in 'Kotata' blackberry in alternate-year production. J. Hort. Sci. and Biotech. 76:700-708.

Naraguma, J. J.R. Clark, R.J. Norman, and R.W. McNew. 1999. Nitrogen uptake and allocation by field-grown 'Arapaho' thornless blackberry. J. Plant Nutr. 22:753-768.

Orbović, V., D. Achor, P. Petracek, and J.P. Syvertsen. 2001. Air temperature, humidity, and leaf age affect penetration of urea through grapefruit leaf cuticles. J. Amer. Soc. Hort. Sci. 126:44-50.

Pritts, M.P. and D. Handley. 1998. Strawberry production guide (eds.). North Reg. Agr. Eng. Ser., Ithaca, N.Y.

Reickenberg, R.L. and M.P. Pritts. 1996. Dynamics of nutrient uptake from foliar fertilizers in red raspberry (Rubus idaeus L.). J. Amer. Soc. Hort. Sci. 121:158-163.

Rempel, H.G. 2003. Nitrogen use and management in red raspberry, M.S. thesis. Ore. State Univ.

Retamales, J.B. and E.J. Hanson. 1989. Fate of ${ }^{15} \mathrm{~N}$-labeled urea applied to mature highbush blueberries. J. Amer. Soc. Hort. Sci. 114:920-923.

Rodgers, C.O., E. Izsak, U. Kafkafi, and S. Izhar. 1985. Nitrogen rates in strawberry (Fragaria ananasa) nursery on growth and yield in the field. J. Plant Nutr. 8:147-162.

Rosen, C.J., E.E. Hoover, and J.J. Luby. 1988. Influence of foliar-applied N-P-K fertilizers on productivity and nutrition of June-bearing strawberries. Can. J. Plant Sci. 68:277-282.

Sanchez, E.E., T.L. Righetti, D. Sugar, and P.B. Lombard. 1990. Response of 'Comice' pear tress to a postharvest urea spray. J. Hort. Sci. 65: 541-546.

Shim, K.K., J.S. Titus, and W.E. Splittstoesser. 1972. The utilization of postharvest urea sprays by senescing apple leaves. J. Amer. Soc. Hort. Sci. 97:592-596.

Swietlik, D. and M. Faust. 1984. Foliar nutrition of fruit crops. Hort. Rev. 6:287-355.

Ullrich, G. and L. Martin. 1987. Spring applications of nitrogen on strawberries. Proc. Ore. Hort. Soc. 78:142-146.

Voth, V., K. Urin, and R.S. Bringhurst. 1967. Effect of high nitrogen applications on yield, earliness, fruit quality and leaf composition of California strawberries. Proc. Amer. Soc. Hort. Sci. 91:249-256. 